\begin{tabular}{l|l} 
Variants & $\begin{array}{l}\text { Variants } \\
\text { The Journal of the European Society for Textual } \\
\text { Scholarship }\end{array}$
\end{tabular}

$12-13$ | 2016

Varia

\title{
Elena Pierazzo, Digital Scholarly Editing : Theories, Models and Methods
}

\section{Elli Bleeker}

\section{(Q) OpenEdition \\ Journals}

Electronic version

URL: http://journals.openedition.org/variants/408

DOI: 10.4000/variants.408

ISSN: 1879-6095

\section{Publisher}

European Society for Textual Scholarship

\section{Printed version}

Date of publication: 31 December 2016

Number of pages: $280-283$

ISSN: 1573-3084

\section{Electronic reference}

Elli Bleeker, «Elena Pierazzo, Digital Scholarly Editing : Theories, Models and Methods», Variants [Online], 12-13 | 2016, Online since 01 May 2017, connection on 24 September 2020. URL : http:// journals.openedition.org/variants/408 ; DOI : https://doi.org/10.4000/variants.408

This text was automatically generated on 24 September 2020 .

The authors 


\title{
Elena Pierazzo, Digital Scholarly Editing : Theories, Models and Methods
}

\author{
Elli Bleeker
}

\section{REFERENCES}

Elena Pierazzo. Digital Scholarly Editing: Theories, Models and Methods. Farnham, Surrey:

Ashgate, 2015. x, 242 p., ill. ISBN 978-1472412119.

1 What textual scholarship needs now are practical reports "from the editorial trenches", concludes Paul Eggert in his review of David Greetham's Theories of the Text (Eggert 2005, 90). Elena Pierazzo's Digital Scholarly Editing: Theories, Models and Methods, the first comprehensive analysis of the field as it has developed in the past decades, can be considered an answer to that call. However, Pierazzo has much more to report than intelligence from the battlefield. She places numerous accounts of the practice within a broader framework of editorial theories and their historical and social contexts. As such, she continues and expands on notable studies like those of Jerome McGann (1991), Peter Shillingsburg (1996; 2006) and Eggert himself (2009). Her work demonstrates once again how scholarly editing intertwines with various cultural practices, and thus how it affects the current and future conditions of humanities research.

2 The book is structured according to the standard workflow of creating a digital edition. of course, the word "standard" here raises a red flag: there is not one established approach toward digital editing, and this is exactly the topic of the book. Over the course of nine chapters, Pierazzo describes each step a present-day editor can take. The first part of the book (Chapters 1, 3 and 4) focuses mainly on "elements of continuity" (5) within editing, be it print or digital. It discusses for instance the debate on objectivity and provides conclusive definitions for concepts like text, work and 
document. This is a necessary exertion and Pierazzo dutifully discusses the main theoretical positions, but she implicitly makes clear that it is time to move beyond such debates. In the second part of the book, Pierazzo goes on to discuss the issues more specifically related to digital editing in a similar brisk manner. Stand-off markup might offer a solution to overlapping XML hierarchies, but it is not free of interpretation (Chapter 5); the main users of scholarly editions are scholars, even when the literary work may have a larger reading public (Chapter 7); and it is incredibly difficult to name and define the product of digital editing (Chapter 9). Taken together, her conclusive statements deliver a clear message: now that we know the history of the field, now that we fully grasp the concepts and understand the different approaches towards them, let's get to work.

3 In order to work optimally with the computer, digital editors need a model of the text and preferably also of the complete editorial practice (38). Consequentially, modelling is one of the central themes of this book (Chapters 2 and 3). Following the arguments of Willard McCarty $(2004 ; 2005)$, Pierazzo emphasizes that the making of a model can be as constructive as the model itself. The repetitive process of modelling, testing, (possibly failing) and reconceptualizing has intrinsic intellectual value (63). Through an analysis of the merits and shortcomings of existing models (e.g. DeRose et al. 1990; Sahle 2013), Pierazzo presents a conceptual model that forms the implicit foundation for the rest of the book. It is important to note that here, and elsewhere throughout the book, she remains constructive in her critique. Failure is, after all, an essential part of modelling. Perhaps difficult to accept for scholars who usually strive for nothing less than perfection, but Pierazzo considers it a prerequisite for "sustainable innovation" (204).

Her mastery of the topic - and her enthusiasm for it - is evident when she writes about the various aspects of digital editing. Some footnotes constitute amusing short stories on their own, such as the anecdotes about the title of McLuhan's famous work (67) or the sixteenth-century editor/publisher Francesco Domi (127). Each chapter presents practical examples, often taken from her own experience as philologist and digital editor, are neatly wrapped in an introductory status quaestionis and a conclusive statement suggesting a number of directions in which the field might develop. Some of these explorations are relatively short, but the chapter $s$ are so entwined with references and citations that the interested reader has enough starting points for further reading. Pierazzo also acknowledges that for many of the issues she brings up there is no clear-cut solution, the answer often being "it depends" (76 and 120) or "in need of further work" (157). This is not necessarily a flaw of the book, nor an easy "time will tell"-answer: it merely illustrates the versatility of a field in full development.

5 As expected, the author identifies challenges in the areas of publication and sustainability, the notorious Achilles' heels of digital scholarly editing. Possible solutions can be found along the lines of a revision of the partnership with the publishing world (see chapter 6). Additionally, Pierazzo suggests that scholarly editors produce both simplified reading editions for a larger audience as well as scholarly editions for study purposes. Another, more original concern is the continuation of innovative research, currently threatened by a guarded mentality of both editors and funding bodies. She proposes to distinguish two parallel strands of digital editing: one that concentrates on the production of digital editions, and another, more experimental or "daring" digital editing. As a proper research activity, the latter would 
on principle allow for innovative experimentation (and failure!): editions as "laboratories of textual scholarship" (204).

It is true that, due to the rapid developments over the past thirty years, the present editorial discourse is laced with catchphrases such as "we are only at the beginning". Yet, when reading Digital Scholarly Editing, one has indeed the exhilarating feeling of being at the outset of exciting times, of having an actual chance at witnessing those sweeping changes in the near future. The book's central objective is simple yet effective: examine the present-day digital editions vis-à-vis their history and future potential. In other words, where do we come from, where do we want to go, and how do we get there? Pierazzo has clear ideas about the directions in which to move and backs her arguments by a thorough study of changing editorial concepts. One can read this book without having a solid background in textual scholarship and still understand the concepts she discusses. As a consequence, this work is engaging not only for practitioners of digital editing, but for a much wider audience as well.

\section{BIBLIOGRAPHY}

DeRose, Stephen J. et al. 1990. "What is Text, Really”, Journal of Computing in Higher Education, I (2), pp. 3-26.

Eggert, Paul. 2005. “These Post-Philological Days”. Ecdotica, 2, pp. 80-98.

Eggert, Paul. 2009. Securing the Past: Conservation in Art, Architecture and Literature. Cambridge: Cambridge University Press.

McCarty, Willard. 2004. "Modeling. A Study in Words and Meanings". In Susan Schreibman, Ray Siemens and John Unsworth (eds.), A Companion to Digital Humanities. Oxford: Blackwell, pp. 254270.

McCarty, Willard. 2005. Humanities Computing. Basingstoke: Palgrave Macmillan.

McGann, Jerome J. 1991. The Textual Condition. Princeton: Princeton University Press.

Sahle, Patrick. 2013. Digitale Editionsformen: Zum Umgang mit der Überlieferung unter den Bedingungen des Medienwandels. 3 vols. Norderstedt: Books on Demand.

Shillingsburg, Peter. 1996. Scholarly Editing in the Computer Age: Theory and Practice. Ann Arbor: University of Michigan Press.

Shillingsburg, Peter. 2006. From Gutenberg to Google: Electronic Representations of Literary Texts. Cambridge: Cambridge University Press. 


\section{AUTHORS}

\section{ELLI BLEEKER}

Elli Bleeker is a research fellow for the Marie Curie-funded "Digital Scholarly Editions Initial Training Network" (DiXiT). She is also a PhD candidate at the Centre of Manuscript Genetics of the University of Antwerp, investigating the textual genesis of a modern literary work and how this can be embedded in the infrastructure of a digital edition. 